\title{
Językoznawstwo wobec odkryć genetyki Na przykładzie niektórych problemów związanych z tzw. genem języka
}

\section{Agnieszka Libura, Maria Libura}

Uniwersytet Wrocławski, Uczelnia Łazarskiego

\section{Wstęp}

W rozdziale tym pragniemy rozważyć trzy kwestie. Po pierwsze, omówimy krótko - niezwykle interesującą z punktu widzenia zarówno językoznawstwa, jak i metodologii badań naukowych - historię odkrycia tzw. genu języka, czyli genu FOXP2, znajdującego się u człowieka w regionie q31 chromosomu 7 pary $^{1}$. Po drugie, zwrócimy uwagę na pewne problemy z komunikacja interdyscyplinarną, które się w tym przypadku ujawniły. To właśnie te trudności - jak sądzimy - leżały u podłoża przedwczesnych i w dużej mierze błędnych twierdzeń, jakie znalazły się w pierwszych pracach analizujących przypadek rodziny, w której mutacja genu FOXP2 towarzyszyła zaburzeniom rozwoju językowego. Skupimy się zwłaszcza na nieporozumieniach, związanych z rolą czynników genetycznych w etiologii zaburzeń umiejętności językowych, które prowadzić mogą niektórych językoznawców do nierealistycznych oczekiwań wobec genetyki. Czy w ogóle można umiejętności językowe zlokalizować w konkretnych genach?

Mamy zamiar pokazać, jak założenia na temat wrodzonego i modularnego charakteru języka, przyjmowane za oczywiste przez wielu językoznawców, których badania mieszczą się w głównym nurcie współczesnej lingwistyki, prowadziły do preselekcji i wybiórczej analizy danych na temat genu FOXP2. W wyniku takiego podejścia wiele istotnych obserwacji oraz wyników badań,

\footnotetext{
${ }^{1}$ Wszystkie organizmy komórkowe mają struktury, które nazywamy chromosomami, zawierające geny zapisane w postaci sekwencji nukleotydów DNA. Kompletny zestaw chromosomów danego gatunku nazywamy kariotypem. Kariotyp człowieka składa się z 22 par autosomów i pary chromosomów płciowych (por. Flecher i in. 2010: 86-87).
} 
które nie pasowały do obrazu modularnego, rozwijającego się niezależnie od innych modalności percepcyjnych czy funkcji poznawczych, języka-organu, zostało zupełnie zignorowanych lub przypisano im marginalne znaczenie. W tym kontekście chcemy zwrócić uwagę na pewne ograniczenia paradygmatu natywistycznego i modularyzmu w językoznawstwie, zwłaszcza związane z nieuzasadnionym ograniczaniem zakresu badań nad zaburzeniami rozwoju języka.

\section{FOXP2. Gen języka?}

$\mathrm{Na}$ początku lat dziewięćdziesiątych dwa czasopisma Nature i Cognition opublikowały wyniki badań nad zaburzeniami rozwoju języka w dużej, trzypokoleniowej rodzinie (Gopnik 1990; Gopnik, Crago 1991). Blisko połowa członków rodziny (znanej w literaturze przedmiotu jako rodzina KE) reprezentowała fenotyp ${ }^{2}$, za którego najbardziej uderzającą cechę uznano poważne zaburzenia języka i mowy. Sporządzone na podstawie tych i późniejszych analiz drzewa genealogiczne KE wskazywały na autosomalny dominujący tok dziedziczenia zaburzeń w badanej rodzinie (rysunek 1).

Myrna Gopnik twierdziła, że upośledzenie to zostało spowodowane prawdopodobnie defektem pojedynczego genu. Ponieważ chorzy członkowie rodziny, jak wynikało z pierwszych obserwacji, nie potrafili się nauczyć regularnych morfemów gramatycznych (gramatyki), chociaż byli w stanie opanować nieregularne morfemy (leksykon), zatem - uznała Gopnik - przypadek ten potwierdzał hipoteze istnienia wrodzonego genetycznego mechanizmu, odpowiedzialnego za poszczególne aspekty struktury językowej. Ujmując rzecz precyzyjniej, Gopnik sugerowała, że dotknięci zaburzeniami członkowie rodziny nie potrafią, wychodząc od poszczególnych form fleksyjnych (takich jak watched czy washed), dojść do ogólnej reguły gramatycznej (w tym przypadku: reguły tworzenia czasu przeszłego). Początkowo Gopnik zaproponowała jako wyjaśnienie hipotezę, że wynika to z braku reprezentacji umysłowej określonych cech gramatycznych. Taka 'ślepota na cechy' miała wynikać z faktu, że ich wrodzony, biologiczny mechanizm, odpowiadający za rozwój gramatyki, został uszkodzony. Gdy okazało się, że dotknięci zaburzeniem członkowie rodziny rozróżniają cechy gramatyczne, np. prawidłowo wskazują obrazki, przedstawia-

${ }^{2}$ „Każda cecha, którą możemy zaobserwować, i która jest dziedziczna, taka jak kolor oczu, kształt liścia, choroba dziedziczna, np. mukowiscydoza (cystic fibrosis), to fenotyp. [...] Zespół genów odpowiedzialny za fenotyp danego osobnika to genotyp" (Fletcher i in. 2010: 162). 
jące pojedynczy przedmiot lub grupę przedmiotów w zależności od użycia formy liczby pojedynczej lub mnogiej, hipoteza ta została odrzucona. Zamiast niej Gopnik i Crago (1991) zaproponowały następujące wyjaśnienie: osoby z SLI rozróżniają cechy gramatyczne, ale nie potrafią na podstawie dostępnych danych stworzyć paradygmatów (reguł) gramatycznych, i każdego słowa uczą się tak, jakby było ono nieregularne.

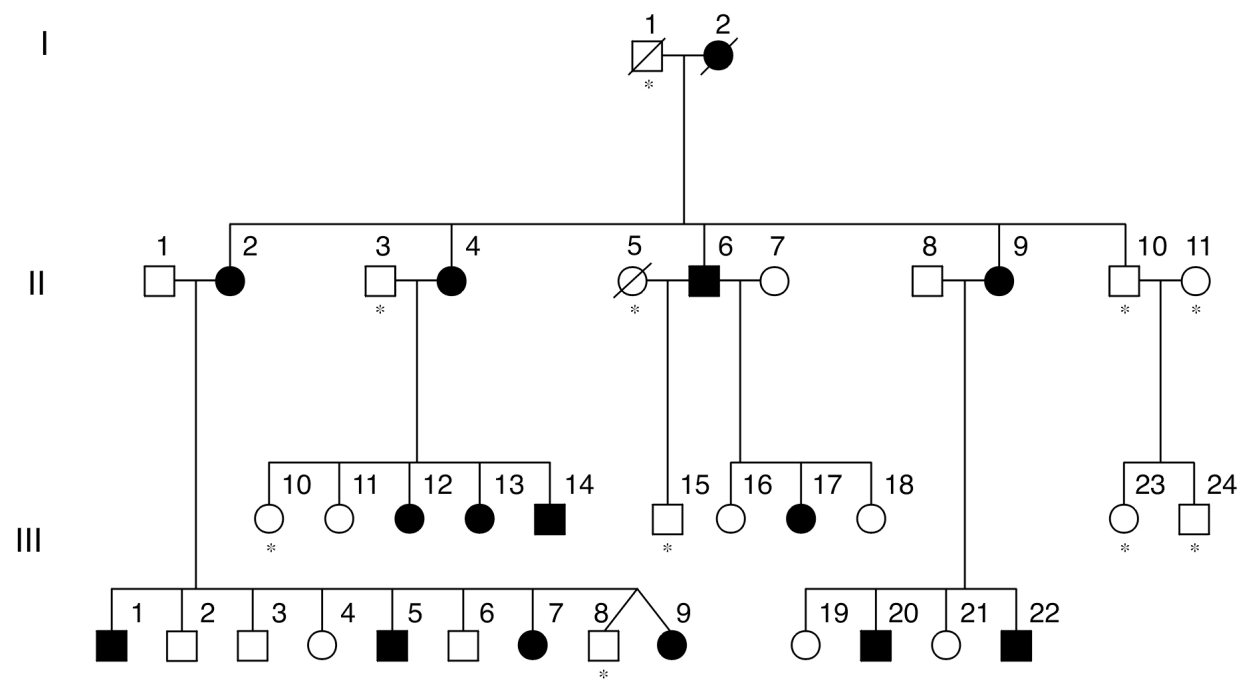

Rysunek 1. Drzewo genealogiczne rodziny KE (według: Vargha-Khadem i in. 1998: 12696)

Objaśnienia: cyfry rzymskie oznaczają pokolenia, a cyfry arabskie kolejnych członków rodziny w obrębie pokolenia; czarne figury symbolizują chorych członków rodziny, białe - zdrowych, koła - kobiety, a kwadraty - mężczyzn; zgon członka rodziny został zaznaczony za pomocą przekreślenia odpowiedniej figury

Badania nad rodziną KE stały się szeroko znane dzięki Stevenowi Pinkerowi (1994), który w swojej głośnej książce The Language Instinct twierdził, że opisany przez Gopnik przypadek jest szczególnie dramatycznym przykładem specyficznego zaburzenia rozwoju mowy i języka (SLI). Zaburzenie to, wedle międzynarodowej klasyfikacji chorób i klasyfikacji ICD-10, charakteryzuje się upośledzeniem normalnych wzorców nabywania umiejętności językowych od wczesnych stadiów rozwoju, przy czym stanów tych nie można bezpośrednio wiązać z zaburzeniami neurologicznymi, nieprawidłowościami mechanizmów mowy, zaburzeń sfery czuciowej, upośledzeniem umysłowym lub czynnikami środowiskowymi (International Statistical Classification of Diseases... 2007). 
Zauważmy, że paradygmat natywistyczno-modularny przewiduje wystapienie takiej dysocjacji pomiędzy rozwojem językowym a rozwojem inteligencji niewerbalnej. Skoro język rozwija się niezależnie, powinny znaleźć się przykłady osób z dobrze rozwiniętą inteligencją ogólną i zaburzeniami gramatycznymi, i odwrotnie. $Z$ tego też powodu SLI przyciagało uwagę badaczy z tego nurtu. Brakowało tylko dowodu na wrodzoność tej dysfunkcji, toteż przypadkowi rodziny KE szybko nadano rozgłos, twierdząc, że oto znaleziono przykład uszkodzenia na poziomie molekularnym wrodzonego, 'biologicznego' modułu gramatycznego.

Przypadek rodziny KE miał potwierdzać hipotezę genetycznego podłoża zdolności do nabycia gramatyki. Jak ujął to autor The Language Instinct, regularność występowania zaburzeń w tej rodzinie przypomina klasyczny model dziedziczenia zgodnie z prawami Mendla:

W rzeczy samej, współpracujący z Gopnik genetycy zauważyli, że sposób dziedziczenia wskazuje na występowanie cechy uwarunkowanej pojedynczym genem dominującym, zupełnie jak w przypadku różowych kwiatów groszku Grzegorza Men$\mathrm{dla}^{3}$ (Pinker 1994: 49).

Kiedy w końcu odkryto obecność mutacji w genie FOXP2, zlokalizowanym na siódmym chromosomie (Lai i in. 2001), gen ów zaczęto dość powszechnie określać genem języka lub nawet genem gramatyki. Duże poruszenie wśród badaczy wywołał fakt, że opisywana mutacja dotyczyła tylko jednego aminokwasu: zamiast argininy u chorych członków rodziny KE pojawiła się histydy$\mathrm{na}^{4}$. Jednocześnie niektórzy badacze zaczęli w tym odkryciu upatrywać ostateczny dowód na wrodzony charakter języka. Zwłaszcza laikom czytającym popularnonaukowe doniesienia na temat genu FOXP2 wydawało się to oczywiste: jeden gen odpowiada jednej cesze fenotypu, mianowicie językowi.

Tymczasem zaledwie kilka miesięcy po ukazaniu się pierwszego tekstu Gopnik na temat zaburzeń rozwoju językowego w rodzinie KE inny zespół badaczy, na którego czele stała Faraneh Vargha-Khadem (Vargha-Khadem, Passingham 1990), późniejsza współodkrywczyni mutacji genu FOXP2, wskazał na istotne błędy popełnione przez Gopnik w opisie tego przypadku. Po pierwsze, zaobserwowano, że upośledzeni członkowie rodziny KE regularnie dokonywali nadmiernych generalizacji. W pracy The 'Language Instinct' Debate, podejmującej dyskusję nad tezą o wrodzonym charakterze języka, Geoffrey Sampson

${ }^{3}$ „In fact, the geneticists working with Gopnik noted that the pedigree suggests a trait controlled by a single dominant gene, just like pink flowers on George Mendel's pea plants".

${ }^{4}$ Warto dodać, że arginina występuje regularnie i niezmiennie we wszystkich genach typu FOX w tym miejscu, w którym na skutek mutacji w rodzinie KE pojawiła się histydyna. 
i Paul Postal ocenili, że wyniki te stoją w jawnej sprzeczności z tezą Gopnik, ponieważ nadmierna generalizacja wymaga stworzenia ogólnej reguły gramatycznej:

Nadmierna generalizacja to rodzaj błędu, który może powstać jedynie wskutek zastosowania reguły ogólnej (w odniesieniu do przypadku, w którym nie powinna być stosowana). Jeśli członkowie rodziny KE nie byliby w stanie posługiwać się regułami rządzącymi tworzeniem różnych form czasownikowych, jak twierdziła Gopnik, byłby to ten rodzaj błędu, którego popełnianie nie powinno im grozić ${ }^{5}$ (Sampson 2005: 123).

Ponadto kolejne badania dowiodły, że w rodzinie KE osoby upośledzone, które - jak potem wykazano - mają zmutowany gen FOXP2, cierpią na szereg różnorodnych zaburzeń. Należy do nich zaliczyć m.in.:

- niższą inteligencję;

- problemy artykulacyjne;

- upośledzenie mimiki twarzy i ruchów ust, niezwiązanych z artykulacją językową;

- nietypową architekturę mózgu (Vargha-Khadem i in. 1995).

Podsumowując wyniki swoich pięcioletnich badań nad osobami chorymi w rodzinie KE, Vargha-Khadem już w roku 1995 twierdziła, że upośledzenie kognitywne w tym przypadku nie ogranicza się do problemów gramatycznych, ale obejmuje zarówno problemy językowe różnej natury, jak i pozajęzykowe. Według niej:

Jest oczywiste, że zaburzenia poznawcze dotkniętych mutacją członków rodziny nie ograniczają się do problemów morfosyntaktycznych. Wydają się raczej obejmować obszar zdolności werbalnych jako takich, a w równym stopniu dotyczą zdolności niewerbalnych ${ }^{6}$ (Vargha-Khadem $i$ in. 1995: 932).

Po zidentyfikowaniu mutacji genu FOXP2 (Lai i in. 2001) badacze zajęli się w dalszej kolejności ewolucją tego genu (Enard i in. 2002), jego rolą w rozwoju innych gatunków (Teramitsu i in. 2004) oraz neuronowym fenotypem osób

5 „An overgeneralization is a type of error that can only be produced by applying a general rule (to a case where it should not be applied). If the KE subjects had no ability to operate with general rules for verb tenses, as Gopnik claimed, then this was one kind of mistake they should be quite safe from making".

${ }^{6}$ It is clear that a cognitive impairment of the affected family members is not confined to morphosyntax. Rather, it appears to extend to the verbal domain in general, and, indeed, is just as great in the nonverbal domain". 
z mutacją FOXP2 (Belton $\mathrm{i}$ in. 2003; Lai i in. 2003; Liegeois i in. 2003; Vargha-Khadem $i$ in. 2005). Intensywne badania neurologiczne pozwoliły wówczas odkryć, że u chorych członków rodziny KE występują liczne anomalie w rozwoju obu półkul mózgowych, zwłaszcza w okolicach odpowiedzialnych za motorykę. Być może najbardziej uderzającą anomalią było zmniejszenie obu jąder ogoniastych blisko o $25 \%$ w porównaniu do zdrowych członków rodziny KE oraz odpowiedniej wiekowo grupy kontrolnej. U osób z mutacją genu FOXP2 stwierdzono także wyraźną korelację między wielkością jąder ogoniastych a stopniem kontroli ruchów ust w ogólności oraz artykulacji w szczególności.

Co więcej, objętość jąder ogoniastych wykazywała istotną korelację z wynikami, jakie upośledzeni członkowie rodziny uzyskiwali na teście praksji oralnej, teście powtarzania nieistniejących słów oraz teście kodowania skali inteligencji Wechslera. Korelacje wyników dwu pierwszych testów wskazują, że zachodzi związek pomiędzy nietypowym rozwojem wspomnianego jądra a upośledzeniem zdolności motorycznych mięśni twarzy oraz artykulacji, jakie występują w rodzinie $\mathrm{KE}^{7}$ (Vargha-Khadem i in. 2005: 133).

Kolejną osobliwością w rozwoju mózgu u osób z mutacją genu FOXP2 była niewielka grubość istoty szarej w niektórych rejonach obu półkul, np. we wspomnianych jądrach ogoniastych czy w okolicy Broki, podczas gdy w innych rejonach wykryto ponadprzeciętnie wysoki poziom tej substancji. Jak dowodzi Vargha-Khadem i in. (2005), anomalie w budowie mózgu u osób z mutacją genu FOXP2 dotyczą przede wszystkim rejonów istotnych dla procesowania sekwencyjnego i planowania motorycznego ruchów twarzy, a zwłaszcza ust. W świetle tych odkryć trudno byłoby utrzymywać, że chorzy członkowie rodziny KE cierpią na specyficzne zaburzenie rozwoju języka (SLI), a FOXP2 jest genem kodującym jedną cechę fenotypu, a mianowicie język.

Mimo to nadal wielu przedstawicieli językoznawstwa i psycholingwistyki podtrzymuje stanowisko, jakoby przypadek zaburzeń w rodzinie KE należało rozpatrywać jako upośledzenie czysto gramatyczne, a odkrycie FOXP2 stanowiło mocny argument, przemawiający za modularną i natywistyczną koncepcją języka. Jako przykład możemy tu przytoczyć polskie prace z zakresu psycholin-

\footnotetext{
${ }^{7}$ „Moreover, the volume of the caudate nuclei correlated significantly with the performance of the affected family members on a test of oral praxis, a test of non-word repetition and the coding subtest of the Wechsler Intelligence Scale. These correlations on the first two tests suggest a relationship between the abnormal development of this nucleus and the impairments in oromotor control and articulation seen in KE family".
} 
gwistyki ${ }^{8}$. Już w pierwszych zdaniach przedmowy do drugiego wydania swojej znakomitej skądinąd książki Psychologia języka $i$ komunikacji Ida Kurcz (2005: 9) wskazuje na identyfikację genu FOXP2 jako na odkrycie o fundamentalnym znaczeniu dla badań nad językiem z punktu widzenia psychologii. Badaczka twierdzi dalej, że FOXP2 jest genem językowym, a jego istnienie uznaje za jeden $\mathrm{z}$ ważniejszych argumentów przemawiających na rzecz wrodzoności gramatyki uniwersalnej (w sensie Noama Chomsky'ego ${ }^{9}$ ), której cechą charakterystyczną jest modularność (Kurcz 2005: 29-30). Wspomina także w tym kontekście o badaniach nad rodziną KE, której przypisuje, zgodnie z pierwszymi doniesieniami Gopnik, zaburzenia rozwoju językowego ograniczone do gramatyki:

Sprawa genu językowego, postulowanego od dawna, stała się w ostatnich latach szczególnie żywa, kiedy w roku 2001 opublikowano w Nature doniesienie autorstwa Lai i innych o odkryciu na chromosomie 7 genu FOXP2, który doskonale pasował do typu zaburzeń rozwoju językowego (SLI) obserwowanych w rodzinie KE [...]. Dziedziczenie tego zaburzenia przebiegało zgodnie z prawami Mendla (Kurcz 2005: 49).

W tym miejscu warto zadać kilka pytań: dlaczego tak poważne nieporozumienia związane z rolą genu FOXP2 zostały dość bezkrytycznie zaakceptowane przez wielu badaczy języka? Dlaczego Pinker zignorował pierwsze prace Varghi-Khadem, pozwalając na to, aby szeroko rozpowszechniły się w ogromnej mierze nieprawdziwe rewelacje na temat specyficznych zaburzeń rozwoju językowego (SLI) w rodzinie KE i ich genetycznego podłoża? Wielu badaczy tak jak cytowana poprzednio Kurcz - nadal uznaje hipotezę, że FOXP2 jest genem gramatyki, za najbardziej przekonującą, mimo iż nie jest ona spójna z wynikami badań. Uważamy, że - mówiąc najogólniej - można próbować odpowiedzieć na te pytania na dwa sposoby:

${ }^{8}$ Jak zauważa Barbara Lewandowska-Tomaszczyk (2008), relacjonując współczesne spory na temat istoty języka, problem genu FOXP2 powraca w ważnej dyskusji, dotyczącej zdolności językowej i ewolucji języka: podczas gdy Pinker i Jackendoff uznają FOXP2 za gen związany z językiem, Chomsky, Fitch i Hauser twierdzą, że ,gen FOXP2, jak wykazuje szereg eksperymentów, występuje u wszystkich kręgowców, zatem nie może być uznany za 'gen językowy'” (Lewandowska-Tomaszczyk 2008: 20). To krótkie streszczenie sporu zdaje się wskazywać na szereg nieporozumień. Niektóre z nich - m.in. związane z relacją genotyp - fenotyp - omówimy w dalszej części rozdziału nieco szerzej. Tu zwrócimy uwagę jedynie na błędne przekonanie, że gen FOXP2 występuję w identycznej postaci u wszystkich kręgowców. Wprawdzie geny typu FOX są silnie konserwowane, ale i one podlegają ewolucji (por. Enard i in. 2002).

${ }^{9}$ Kurcz (2005: 27) odwołuje się przy tym do dwóch wersji opisu gramatyki uniwersalnej: teorii zasad i parametrów (Chomsky 1981) oraz do programu minimalistycznego (Chomsky 1995). 
- wskazując na poważny problem komunikacji interdyscyplinarnej, z którego wypływają błędne koncepcje działania kodu genetycznego;

- poszukując przyczyny nieporozumień w założeniach na temat szczególnie rozumianego wrodzonego i modularnego charakteru języka, przyjmowanych za oczywiste przez wielu językoznawców, których badania mieszczą się w głównym nurcie współczesnej lingwistyki.

\section{Co kodują geny?}

W cytowanych uprzednio pracach badaczy zainteresowanych wrodzonym charakterem języka dwukrotnie - raz u Pinkera, a raz u Kurcz - pojawiło się nazwisko pioniera genetyki, Mendla, i odniesienia te wydają się pośrednio wskazywać na zakres wiedzy genetycznej, uwzględnianej w pracach współczesnych językoznawców i psychologów języka. Jak można się domyślać, wiedza ta nierzadko ogranicza się do znajomości wyników klasycznych eksperymentów z krzyżowaniem grochu o różnych kolorach kwiatów i przekonania, że daną cechę fenotypu koduje jeden gen, przy czym istnieją geny dominujące i recesywne. Odkrycie 'genu gramatyki' bez watpienia opierało się na kilku nieporozumieniach, związanych z niezwykle uproszczonym i częściowo historycznym rozumieniem kodu genetycznego. Zakładano mianowicie, że

- gramatyka jest prostą cechą fenotypu, taką jak kolor oczu;

- proste cechy sa kodowane przez pojedyncze geny;

- mutacja jednego genu powoduje zmianę jednej cechy i może być dalej dziedziczona według modelu opisanego przez Mendla.

Od czasu Mendla genetyka jednak poczyniła pewne postępy. Dziś wiemy, że relacja pomiędzy genotypem a fenotypem ma naturę złożoną, i nie każda cecha organizmu kodowana jest przez pojedynczy gen. Wynika to ze sposobu, w jaki informacja biologiczna zakodowana w łańcuchu DNA w postaci sekwencji zasad udostępniana jest komórce. Dokonuje się to w skomplikowanym procesie, który nazywany jest ekspresją genów. Podczas ekspresji cząsteczki DNA przekazują zawartą $\mathrm{w}$ nich informację, kierując syntezą cząsteczek RNA o sekwencji komplementarnej do sekwencji DNA. Tak utworzony RNA kieruje następnie syntezą polipeptydów, których sekwencję aminokwasów determinuje sekwencja zasad RNA. Sekwencja aminokwasów w białku determinuje jego strukturę, a ta z kolei dyktuje funkcję białka (por. Fletcher i in. 2010: 10).

Dzięki nowym metodom biologii molekularnej, pozwalającym badać niektóre regiony genomu, a nie jedynie obserwować fenotypy, zrewidowano nawet modele dziedziczenia pozornie prostych cech, takich jak kolor oczu u ludzi. Pierwotnie zakładano, że barwa tęczówki zależy od tego, jakie kopie 
pewnego genu dziecko otrzyma od rodziców, przy czym gen brązowych oczu miał być dominujący, a niebieskich - recesywny.

Okazało się jednak, że model ten nie jest w stanie opisać różnorodności barw ludzkich oczu występujących w rzeczywistości. Dalsze badania dowiodły, że $\mathrm{w}$ istocie mechanizm dziedziczenia koloru tęczówki opiera się na wielu genach, które znajdują się na różnych chromosomach. Wedle ostatnich badań, za kolor oczu odpowiada blisko 16 genów (White i Rabago-Smith 2010)! Co więcej, geny nie kodują koloru oczu w sposób bezpośredni, a jedynie regulują wewnątrzkomórkowy transport cząsteczek, odpowiedzialnych za pigmentację skóry, włosów i oczu. Regularne przyjmowanie pewnych lekarstw, takich jak prostaglandyny $\mathrm{i}$ ich analogi $\mathrm{w}$ postaci kropel do oczu, przepisywanych w przypadku jaskry, może wpływać na transport tych cząsteczek, co prowadzi do trwałej zmiany koloru oczu.

Omówiony przykład wydaje się dobrze ilustrować dwie prawidłowości, które - jak sądzimy - umykały wielu badaczom, będącym zwolennikami hipotezy o wrodzonym charakterze języka:

- nawet relatywnie proste cechy, takie jak kolor oczu, mogą zależeć od wielu genów;

- relacja między genotypem a fenotypem jest skomplikowana; pomijając kwestie interakcji wielu genów, na rozwój i stabilność danej cechy mają wpływ czynniki środowiskowe.

Relacje między genotypem a fenotypem komplikuje fakt, że nie tylko jedna cecha może zależeć od wielu genów, ale i dany gen może ulegać ekspresji w wielu narządach. Okrzyknięty genem języka FOXP2 ulega ekspresji m.in. w jelitach, sercu i płucach (Shu i in. 2001), a także w wielu rejonach mózgu, takich jak jądro ogoniaste i skorupa, jądra wzgórza, jądro zębate móżdżku, płaciki móżdżku, istota czarna siatkowata i gałka blada przyśrodkowa, okolica Broki i okolice premotoryczne oraz kora motoryczna (Vargha-Khadem i in. 2005). Jak wykazały badania, mutacja genu FOXP2 nie wpływa na rozwój i stan wszystkich tkanek, w których gen ten ulega ekspresji, i to wybiórcze oddziaływanie okazało się trudne do wyjaśnienia:

Podobnie jak nie jest jasne, dlaczego mutacja występująca w rodzinie KE FOXP2 wpływa na rozwój i funkcjonowanie tkanki mózgowej, choć nie wydaje się mieć znaczenia w przypadku innych tkanek, w których także ulega ekspresji, tak też nie wiadomo, dlaczego mutacja ta, jak wynika z badań, wpływa tylko na niektóre obszary mózgu spośród tych, w których ulega ekspresji ${ }^{10}$ (Vargha-Khadem i in. 2005: 135).

10 ,Just as it is unclear why mutation of FOXP2 in the KE family affects development and maintenance of brain tissue but not, apparently, that of other tissues in which it is expressed, so it is unclear why the KE mutation seems to affect some brain regions in which FOXP2 is expressed but not others". 
Opublikowane cztery lata po odkryciu genu FOXP2 badania mózgu, wykorzystujące technikę neuroobrazowania, wykazały, że u chorych członków rodziny KE anomalie strukturalne lub funkcjonalne występują $\mathrm{w}$ jądrze ogoniastym i skorupie, płacikach móżdżku, okolicy Broki i okolicach premotorycznych oraz korze motorycznej. Zespołowi badaczy pod kierownictwem Varghi-Khadem udało się także zidentyfikować dwa obwody neuronowe, które przypuszczalnie mają wpływ na problemy językowe członków rodziny KE z mutacją genu FOXP2 (rysunek 2). Obie pętle, z których jedna przechodzi przez zwoje podstawy mózgu, a druga przez móżdżek, związane są z funkcjami motorycznymi mięśni twarzy. W konkluzji analizy zależności między ekspresją genu FOXP2 a neuroanatomią języka i mowy badacze stwierdzają, że ich propozycja pozwala wyjaśnić problemy artykulacyjne, obserwowane w rodzinie KE, a także wskazuje na rolę, jaką ten gen może odgrywać w procesie rozwoju języka mówionego u osób, które mają prawidłową kopię genu FOXP2 ${ }^{11}$.

Jak wynika z tych dobrze udokumentowanych badań, związki między mową a genem FOXP2 niewattpliwie istnieja, mają one jednak inną naturę i o wiele większy stopień komplikacji, niż zakładali językoznawcy postulujący istnienie genu języka. Czy można się spodziewać, że w przyszłości uda się powiązać inne zdolności językowe z konkretnymi genami? Wiele złożonych zdolności człowieka, takich jak chodzenie, uznaje się obecnie za osiagnnięcia rozwojowe, których nie można bezpośrednio sprowadzić do działania konkretnych genów. Jak już na to wskazywaliśmy, bezpośrednio geny mają wpływ jedynie na strukturę i funkcjonowanie poszczególnych tkanek. Nawet jeżeli w przyszłości uda się wskazać inne geny związane ze zdolnościami językowymi człowieka, trudno zakładać, że będzie zachodziła między nimi prosta relacja: jeden aspekt języka - jeden gen. Lepsza komunikacja pomiędzy językoznawcami i psychologami a genetykami z pewnością mogłaby pomóc wyeliminować wiele nieporozumień i nierealistycznych oczekiwań, jakie badacze języka wiążą z odkryciami genetycznymi.

\footnotetext{
11 „By integrating the evidence about the neural phenotype of the KE family with the neural expression pattern of FOXP2, the proposed circuitry provides a tentative account not only of how the KE mutation has resulted in the affected members' orofacial and verbal dyspraxia, but also of a way in which the normal FOXP2 gene might have contributed to the emergence of proficient spoken language" (Vargha-Khadem $\mathrm{i}$ in. 2005: 136).
} 


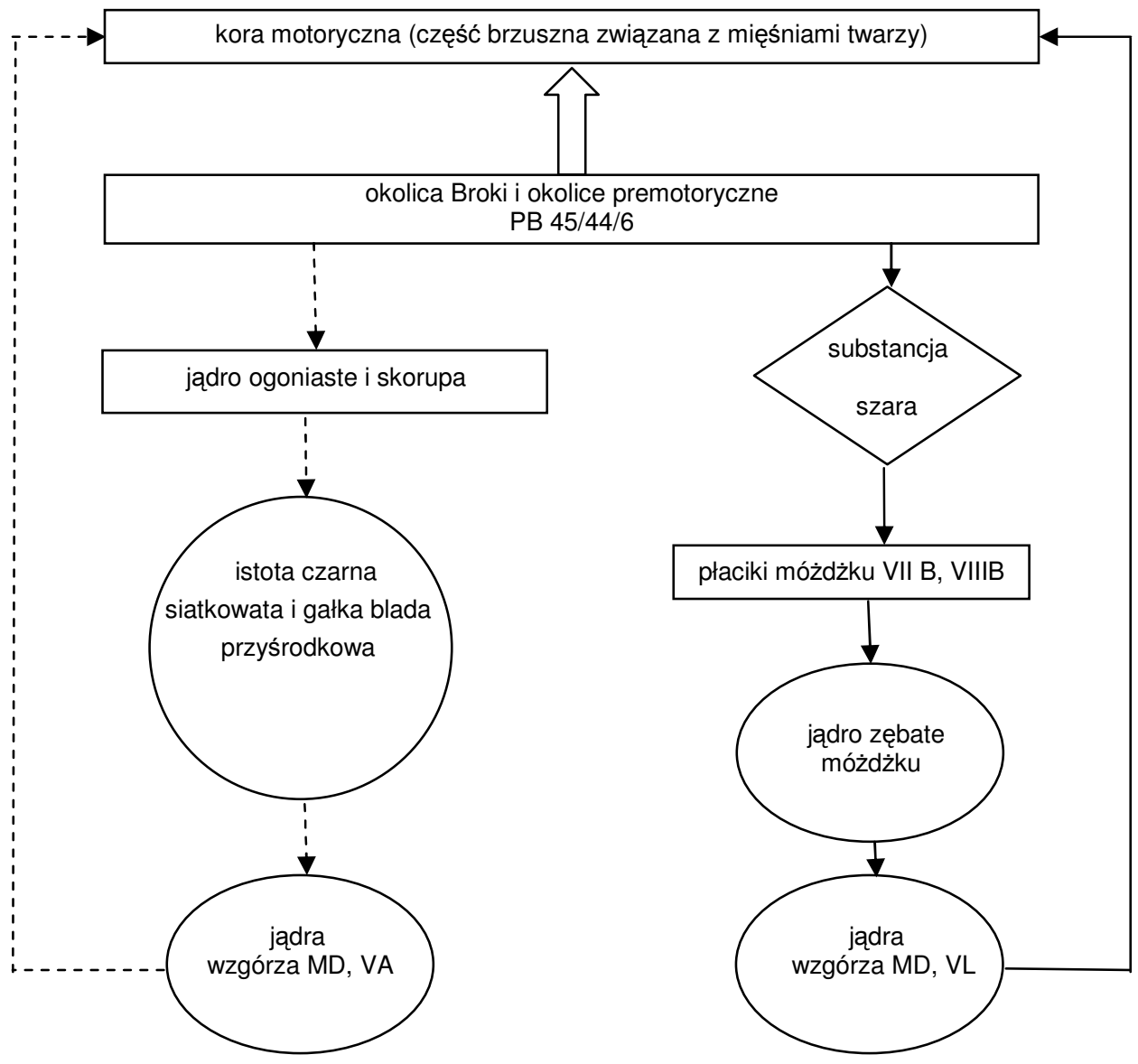

Rysunek 2. Przypuszczalne powiązania między genem FOXP2 a mową (według: Vargha-Khadem i in. 2005: 136). Objaśnienia: strzałki z linią przerywaną oznaczają pętlę przez zwoje podstawy mózgu; strzałki z linią ciągła - pętlę przez móżdżek; elipsy i prostokąty symbolizują struktury, gdzie dochodzi do ekspresji genu FOXP2, przy czym prostokąty odnoszą się do struktur, w których neuroobrazowanie wykazało strukturalne lub funkcjonalne anomalia (u chorych członków rodziny KE); PB oznacza pole Brodmanna, a MD, VA, VL - różne jądra wzgórza

\section{Natywizm i modularyzm a problem genu języka}

U podłoża wybiórczego uwzględniania danych na temat zaburzeń w rodzinie $\mathrm{KE}$, a zatem i dalszych nieporozumień związanych z odkryciem 'genu gramatyki’, leżały także założenia, dotyczące wrodzonego i zarazem modularnego 
charakteru języka. Tezę o wrodzonym charakterze języka jako całości lub przynajmniej pewnych jego aspektów przyjmowało wielu dwudziestowiecznych lingwistów. Teza ta w wersji słabej nie wydaje się tak kontrowersyjna: można się spodziewać, że zdolność do nabywania języka, podobnie jak np. zdolność widzenia, pozostaje w relacji do ludzkiego uposażenia genetycznego. Zwolennicy wrodzonego i modularnego charakteru języka idą jednak dalej: twierdzą, że język rozwija się niezależnie od pozostałych funkcji poznawczych. Najwyraźniej teza ta została wyartykułowana w późniejszych pracach Chomsky'ego, którego wpływ na współczesne językoznawstwo i psycholingwistykę trudno jest przecenic $^{12}$. W często zmieniających się teoriach generatywnych wyjątkowo trwałe i ważne miejsce zajmuje pojęcie gramatyki uniwersalnej. Od początku przyjmowano, że charakterystyczną cechą gramatyki uniwersalnej jest modularność (Kurcz 2005: 23-37). Twierdzono przy tym, że moduły umysłowe:

[...] są wyspecjalizowanymi analizatorami określonych kategorii danych percepcyjnych. Ich operacje są szybkie, obligatoryjne (nie możemy się powstrzymać od usłyszenia czy zobaczenia czegoś, co oddziałuje na nasze zmysły), mają odpowiednią lokalizację mózgową, której uszkodzenie prowadzi do określonych zaburzeń, przyswajane są wedle stałych faz, są teżnieprzenikliwe wobec informacji dla nich niespecyficznych. Moduł językowy musi więc spełniać wszystkie wymienione tu warunki (Kurcz 2005: 29; podkr. A. L. i M. L.).

O ile we wcześniejszych pracach Chomsky uznawał gramatykę uniwersalną za „suplement do gramatyk poszczególnych języków, [...] system warunków nakładających ograniczenia gramatykom wszystkich języków" (Stalmaszczyk 2006: 74), o tyle od drugiej połowy lat osiemdziesiątych ubiegłego wieku przyjął, że gramatyka uniwersalna ,jest teorią stanu początkowego zdolności językowej (zapisaną w genach)" (Stalmaszczyk 2006: 74-75).

Nic zatem dziwnego, że wielu językoznawców i psycholingwistów żyło oczekiwaniem, że genetycy zidentyfikują niebawem gen języka, potwierdzając tym samym przewidywania Chomsky’ego. Jednocześnie wysiłki badawcze skupione zostały na poszukiwaniach dysocjacji pomiędzy rozwojem językowym i rozwojem inteligencji ogólnej, których występowanie przewidywał paradygmat natywistyczno-modularny. Tymczasem w większości przypadków (o ile nie zawsze) zaburzenia mowy towarzyszą zaburzeniom rozwoju intelektualnego. Badanie zależności pomiędzy charakterem dysfunkcji poznawczych i percepcyj-

12 Dopiero w ostatnich latach, jak zauważa Lewandowska-Tomaszczyk (2008: 21), u Chomsky'ego i jego współpracowników można zaobserwować „stopniowe w y c of y w a n i e s i ę z pozycji radykalnej modularności zdolności kognitywnych człowieka, która jawiła się jako sztandarowa teza generatywizmu od czasu hipotezy Jerry Fodora”. 
nych a rodzajem zaburzeń rozwoju języka stało jednak w sprzeczności z założeniami głównego nurtu językoznawstwa formalnego, ponieważ zakładało współzależność rozwoju języka i innych modalności.

Za jeden z przykładów zaskakującej rozbieżności pomiędzy dość dobrym wykształceniem mowy a stosunkowo niskim IQ uchodzi zespół Williamsa. Osoby dotknięte tą rzadką chorobą genetyczną z łatwością posługują się zdaniami złożonymi, a ich słownik jest zwykle bogaty pomimo niskiego ilorazu inteligencji (Bellugi i in. 1988). Niemniej jednak, jak zauważyła Dorothy Bishop (1997: 33), w większości przypadków rozbieżność pomiędzy rozwojem mowy a rozwojem umysłowym nie wygląda już tak zaskakująco, jeśli umiejętności te oceniać nie na podstawie subiektywnego wrażenia, lecz mierzyć za pomocą obiektywnych testów, i zwykle mieści się ona w przedziale upośledzenia umysłowego. Trudno zatem powiedzieć, że mamy tu do czynienia z normalnie rozwiniętymi umiejętnościami językowymi pomimo niskiego ilorazu inteligencji.

Drugą skrajność, czyli zaburzony rozwój językowy przy normalnym rozwoju inteligencji niewerbalnej, stanowi specyficzne zaburzenie rozwoju językowego. Przykładem tego zaburzenia miała być m.in. rodzina KE. Już na jej przykładzie widać, że zaburzenie to przy bliższych badaniach obejmuje więcej aspektów niż tylko mowę. Niemniej jednak nawet jeśli ograniczymy nasze rozważania do aspektów językowych, dostępne dane nie potwierdzają hipotezy 'wrodzonych deficytów gramatycznych', które miałyby pozbawiać osoby z SLI zdolności tworzenia paradygmatów i posługiwania się nimi. Dla przykładu, Leonard, Bortolini i in. (1992) stwierdzili na podstawie badań, że dzieci z SLI dokonują nadmiernych generalizacji reguł gramatycznych podobnie jak zdrowe dzieci, natomiast według Bishop (1994), dzieci z SLI wykazują problemy nie tylko w przypadku odmiany regularnej, ale również nieregularnej.

Koncentracja na poszukiwaniu dysocjacji sprawiła, że w głównym nurcie językoznawstwa zarzucono ciekawą perspektywę wyjaśniającą SLI zaburzeniami percepcji słuchowej i procesowania sekwencyjnego. W roku 1989 pojawiła się 'hipoteza struktury powierzchniowej', zakładająca, że zaburzenia struktur gramatycznych tworzonych przez osoby z SLI można wyjaśniać występującym u nich deficytem percepcji słuchowej sygnałów mowy (Leonard 1989). Morfemy gramatyczne są zazwyczaj krótkie, często niesylabiczne - a zatem mało wyraziste, przez co osobom z takimi deficytami może być trudno je zidentyfikować. Bardzo ciekawe rezultaty przyniosły wcześniejsze badania, porównujące anglo- i włoskojęzyczne dzieci z SLI. Zgodnie z przewidywaniami, opartymi na założeniu o percepcyjnym charakterze zaburzeń SLI, dzieci posługujące się językiem włoskim popełniały znacząco mniej błędów w tych wypadkach, 
w których badane morfemy - znaczniki gramatyczne były sylabiczne (Leonard $\mathrm{i}$ in. 1987, 1988).

Opisywane spory mają nie tylko wymiar teoretyczny, ale całkiem praktyczny. Jeżeli za zaburzenia SLI odpowiadają wrodzone defekty biologicznego mechanizmu nabywania gramatyki, to nie da się ich w żaden sposób usunąć. Jeśli natomiast zaburzenia rozwoju językowego mają swe źródło w upośledzonym przetwarzaniu sygnału słuchowego, to - być może - odpowiednio pomyślana interwencja mogłaby wspomóc rozwój językowy dzieci z SLI. Próbę takiej interwencji podjął Tallal (1996) z zespołem, przeprowadzając z powodzeniem odpowiednio zaprojektowany trening słuchowy na grupie dzieci z SLI.

Także badania genetyczne nad umiejętnościami poznawczymi oparte na analizie wielu zmiennych wskazują, że - przynajmniej w fazie rozwoju zdolność nabywania języka współzależy od rozwoju innych zdolności umysłowych. Z badań, jakie przeprowadził Petrill (1997), wynika, że jeżeli jakiś gen ma wpływ np. na zdolność nabywania języka, to należy się spodziewać, że będzie on wpływać na inne procesy poznawcze, takie jak myślenie przestrzenne itp. Jak zauważa autor, gdyby procesy poznawcze miały charakter modularny i funkcjonowały niezależnie, zgodnie $\mathrm{z}$ właściwymi dla siebie regułami, to należałoby się spodziewać niskiej korelacji genotypowo-fenotypowej pomiędzy różnymi procesami poznawczymi. Tymczasem jest wprost przeciwnie: analizy genetyczne uwzględniające wiele zmiennych przeprowadzone na podstawie badań dzieci i młodzieży, w trakcie których porównywano umiejętności werbalne z poszczególnymi umiejętnościami poznawczymi, wskazują, że wartość tej korelacji wynosi niemal 1 . Zatem $\mathrm{z}$ prawie stuprocentową pewnością można przyjąć, że istnieje ścisły związek zaburzeń językowych i poznawczych.

\section{Bibliografia}

Bellugi, U., Marks, S., Birhle, A., Sabo, H. 1988. „Dissociations between language and cognitive functions in Williams syndrome", [w:] D. Bishop, K. Mogford (red.), $177-189$.

Belton, E., Gadian, D. G., Vargha-Khadem, F. 2003. „Evidence for specific motor programming deficit in development verbal dyspraxia but not SLI", Brain 126, 2455-2462.

Bishop, D. 1994. „Grammatical errors in specific language impairment: competence or performance limitation?", Applied Psycholinguistics 15, 507-549.

Bishop, D. V. M. 1997. Uncommon understanding. Development and Disorders of Language Comprehension in Children, Hove: Psychology Press. 
Bishop, D., Mogford, K. (red.), [1988] 2010. Language Development in Exceptional Circumstances, Edinburgh: Churchil Livingstone.

Enard, W., Przeworski, M., Fisher, S. E., Lai, C. S. L., Wiebe, V., Kitano, T., Monaco, A. P., Paabo, S. 2002. „Molecular evolution in FOXP2, a gene involved in speech and language", Nature 418, 869-872.

Chomsky, N. 1981. Lectures on Government and Binding, Dordrecht: Foris.

Chomsky, N. 1995. The Minimalist Program, Cambridge: MIT Press.

Corballis, M. C., Lea, S. E. G. (red.), 1999. The Descent of Mind, Oxford: Oxford University Press.

Fletcher, H., Hickey, I., Winter, P. 2010. Krótkie wykłady. Genetyka, Warszawa: PWN.

Fodor, J. A. 1983. The Modularity of Mind: An Essay in Faculty Psychology, Cambridge: MIT Press.

Geshwind, N. 1979. „Specialization of the Human Brain”, Scientific American 241 (3), 180-199.

Gopnik, M. 1990. „Feature-blind grammar and dysphasia”, Nature 344, 715.

Gopnik, M., Crago, M. B. 1991. „Familial aggregation of a developmental language disorder", Cognition 39, 1-50.

International Statistical Classification of Diseases and Related Health Problems. 10th Revision. 2007. WHO.

Kurcz, I. 2005. Psychologia języka i komunikacji, wyd. 2, Warszawa: Scholar.

Lai, C. S. L., Fisher, S. E., Hurst, J. A., Vargha-Khadem, F., Monaco, A. P. 2001. „A forkhead-domain gene is mutated in a severe speech and language disorder", Nature 413, 519-523.

Lai, C. S. L., Gerrelli, D., Monaco, A. P., Fisher, S. E., Copp, A. J. 2003. „FOXP2 expression during brain development coincides with adult sites of pathology in a severe speech and language disorder", Brain 126, 2455-2462.

Leonard, L. 1989. „Language learnability and specific language impairment in children”, Applied Psycholinguistics 10, I, 179-202.

Leonard, L., Bortolini, U., Caselli, M. C., McGregor, K., Sabbadini, L. 1992. „Morphological deficits in children with specific language impairment: The status of features in the underlying grammar", Language Acquisition 2, 151-179.

Leonard, L. B., Sabbadini, L., Volterra, V., Leonard, J. S. 1988. „Some influences on the gram mar of English- and Italian- speaking children with specific language impairment", Applied Psycholinguistics 9, 39-57.

Leonard, L. B., Sabbadini, L., Leonard, J. S., Volterra, V. 1987. „Specific language impairment in children: A cross-linguistic study", Brain and Language 32, 233-252.

Lewandowska-Tomaszczyk, B. 2008. „Czym jest język? Współczesne kontrowersje w paradygmatach generatywnych i kognitywnych", [w:] P. Stalmaszczyk (red.), 9-26.

Liegeois, F., Baldeweg, T., Connelly, A., Gadian, D. G., Mishkin, M., Vargha-Khadem, F. 2003. „Language fMRI abnormalities associated with FOXP2 gene mutation”, Nature Neuroscience 6, 1230-1237. 
McManus, I. C. 1999. „Handedness, cerebral lateralization, and the evolution of handedness", [w:] M. C. Corballis, S. E. G. Lea (red.), 194-217.

Petril, S. A. 1997. „Molarity versus modularity of cognitive functioning? A behavioral genetic perspective", Current Directions in Psychological Science 6, 96-99.

Pinker, S. 1994. The Language Instinct, London: Penguin.

Sampson, G. 2005. The 'Language instinct' Debate, London-New York: Continuum.

Shu, W., Yang, H., Zhang, L., Lu, M. M., Morrisey, E. E. 2001. „Characteristics of a new subfamily winged-helix/forkhead (Fox) genes that are expressed in the lung and act as transcriptional repressors", The Journal of Biological Chemistry 276, $27488-27497$.

Stalmaszczyk, P. 2006. „Koncepcje ‘języka' i 'gramatyki' w gramatyce generatywnej i semantyce pojęciowej”, [w:] P. Stalmaszczyk (red.), 74-90.

Stalmaszczyk, P. (red.), 2006. Metodologie językoznawstwa. Podstawy teoretyczne, Łódź: Wydawnictwo UŁ.

Stalmaszczyk, P. (red.), 2008. Metodologie językoznawstwa. Wspótczesne tendencje $i$ kontrowersje, Kraków: Lexis.

Tallal, P., Miller, S. L., Bedi, G., Byma, G., Wang, X., Nagarajan, S. S. 1996. „Language comprehension in language-learning impaired children improved with acoustically modified speech", Science 271, 81-84.

Teramitsu, I., Kudo, L. C., London, S. E., Geshwind, D. H., White, S. A. 2004. „Parallel FoxP1 and FoxP2 expression in songbird and human brain predicts functional interactions", The Journal of Neuroscience 24, 3152-3163.

Vargha-Khadem, F., Gadian, D. G., Copp, A., Mishkin, M. 2005. „FOXP2 and the neuroanatomy of speech and language", Nature Reviews. Neuroscience 6, 131-138.

Vargha-Khadem, F., Passingham, R. 1990. „Speech and language defects”, Nature 346, 226.

Vargha-Khadem, F., Watkins, K., Alcock, K., Fletcher, P., Passingham, R. 1995. „Praxic and nonverbal cognitive deficits in a large family with a genetically transmitted speech and language disorder", Procedures of the National Academy of Science USA 92, 930-933.

Vargha-Khadem, F., Watkins, K., Price, C. J., Ashburner, J., Alcock, K., Connelly, A., Frackowiak, R. S. J., Friston, K. J., Pembreyi, M. E., Mishkin, M., Gadian, D. G., Passingham, R. E. 1998. „Neural basis of an inherited speech and language disorder", Procedures of the National Academy of Science USA 95, 12695-12700.

White, D., Rabago-Smith, M. 2010. „Genotype-phenotype associations and human eye color", Journal of Human Genetics (w druku). 